\title{
An alternative mode of larval development in Scoloplos armiger (O. F. Müller, 1776) (Polychaeta, Orbiniidae)
}

\author{
S. Plate ${ }^{1,2} \&$ E. Husemann ${ }^{1,2}$ \\ 1 Ruhr-Universität Bochum, Lehrstuhl für spezielle Zoologie und Parasitologie, AG \\ Entwicklungsphysiologie der Tiere; Postfach 102148, D-W-4630 Bochum 1, Federal \\ Republic of Germany \\ and \\ ${ }^{2}$ Biologische Anstalt Helgoland, Meeresstation; D-W-2192 Helgoland, Federal Republic \\ of Germany
}

\begin{abstract}
During a three-year plankton monitoring at the island of Helgoland (German Bight, North Sea), pelagic larvae of Scoloplos armiger (O. F. Müller, 1776) were observed to occur regularly from February to April. Up to the present day, only benthic development within egg cocoons has been described (Anderson, 1959). Planktonic larvae comprise early, ovoid trochophores up to advanced stages with 11 setigers. The main morphological difference between the two larval types is the more numerous differentiation of lateral cilia by the pelagic larvae. Annual alterations in appearance and abundance suggest that reproduction is correlated with water temperature.
\end{abstract}

\section{INTRODUCTION}

Scoloplos armiger is a common sedentary polychaete in the North Sea. Comparisons of benthic survey data from the last five decades show a strong increase in population density in the German Bight (Rachor, 1990).

Larval development is usually described as being benthic (Delsman, 1916; Smidt, 1951; Anderson, 1959; Muus, 1967; Gibbs, 1968). Some researchers have reported pelagic larvae (Giere, 1968; Svesnikow, cited in Jägersten, 1972; Wolff, 1973). Benthic development takes place within stalked egg cocoons which are attached to the sand below the mean high water level. Anderson (1959) studied the entire development from eggs to juvenile worms on laboratory cultured individuals. He found that larvae with 9 setigers leave the egg cocoon and immediately burrow in the sand without exhibiting a pelagic phase.

This paper is concerned with the pelagic larvae of $S$. armiger which occur regularly in the spring plankton around Helgoland. Their development, morphology and time of appearance is described.

\section{MATERIAL AND METHODS}

From February 1989 to November 1991 plankton samples were collected by horizontal, surface-near hauls twice a week on Helgoland Roads. For the quantitative samples a net with $75 \mu \mathrm{m}$ mesh size was used. The live material was examined under a dissecting 
microscope soon after collection. After species determination, the larvae were cultured in $5-\mathrm{ml}$ Boveri dishes at $6-8^{\circ} \mathrm{C}$. The natural sea water was changed every five days. The juvenile worms were fed with a suspension of the diatom Phaeodactylum tricornutum.

Light microscopic observations and photographs were made on live individuals with a LEITZ Laborlux K. For SEM studies the larvae were fixed in $2.5 \%$ glutaraldehyde in $0.02 \mathrm{M}$ cacodylate buffer ( $\mathrm{ph} 7.4$ ) and postfixed with $2 \% \mathrm{OsO}_{4}$. After critical-point drying, the specimens were mounted on SEM stubs and coated with gold. SEM observations were made with a ZEISS DSM 930.

\section{RESULTS}

Ovoid trochophores with a length of $300 \mu \mathrm{m}$ are the earliest developmental stages appearing in the plankton. Besides a well developed akrotroch, prototroch and metatroch, they show a weaker telotroch. At this stage, eyes are not visible. Because of their high yolk content the trochophores and also all the following larval stages are lecitotrophic. They appear opaque and orange in colour.

Further larval development occurs as described by Anderson (1959). Compared to his benthic material, our pelagic larvae are smaller and show more numerous ciliary bands on the setiger anlagen. A pelagic larva with six setigers exhibits a body length of about $500 \mu \mathrm{m}$ (Fig. $1 \mathrm{~A}, \mathrm{~B}$ ). In advanced larvae the ciliary bands are replaced by capillary chaetae (Fig. $1 \mathrm{C}, \mathrm{D}$ ). The latest planktonic stage has 10-11 setigers and a body length of $800-900 \mu \mathrm{m}$. The first gills appear at the 10 . segment, and at the pygidium one pair of anal cirri becomes visible (Fig. $1 \mathrm{C}, \mathrm{E}$ ). Examinations on cultured individuals showed that now the competent stage for metamorphosis is reached. After adding a suitable substrate such as fine sand, all individuals transform into juvenile benthic worms within a few hours and start feeding on algae and detritus. In the absence of a suitable substrate, metamorphosis can also take place in the water column, but in this case the success of metamorphosis decreases. At $6-8^{\circ} \mathrm{C}$ the planktic phase lasts 12 days.

Pelagic larvae at different developmental stages occurred in the plankton from February to April. The records showed variations from year to year but these variations were always restricted to a period of about eight weeks (Fig. $2 \mathrm{~A}-\mathrm{C}$ ). Larvae out of the same haul are not always homogenous in age structure, and seasonally earlier samples do not necessarily contain the youngest developmental stages. From March on (60. calendar day), all planktonic stages of Scoloplos armiger can appear; ovoid trochophores are found till the end of March, but larvae with up to nine setigers can be found as early as the end of February. Taking 12 days as the developmental time of the pelagic larvae, reproduction in 1989 and 1990 started in mid-February (Fig. 2 A, B).

In 1991, the first record on 25 March contained exclusively ovoid trochophores. The

Fig. 1 A-E. Scoloplos armiger. A: Pelagic larva with five setiger anlagen. Besides the metatroch segment (mes), two setigers (s) are distinct. B: Dorsal view of a larva with six setiger anlagen (s). The lateral cilia (lc) continue on the ventral side. C: Larval stage with 10 setigers. The ciliary bands are replaced by capillary chaetae (ch). D: Capillary chaeta. E: Final pelagic stage of Scoloplos armiger. At the 10. setiger the first pair of gills $(\mathrm{g})$ appears. One pair of anal cirri $(\mathrm{ac})$ is differentiated at the pygidium. Scale bars: A-C, E $100 \mu \mathrm{m}$; D $2 \mu \mathrm{m}$, ac: anal cirri; ak: akrotroch; ch: chaetae; e: eye; g: gill; lc: lateral cilia; $\mathrm{m}$ : mouth; me: metatroch; mes: metatroch segment; $\mathrm{p}$ : prostomium; $\mathrm{pt}$ : prototroch; s: setiger; t: telotroch 

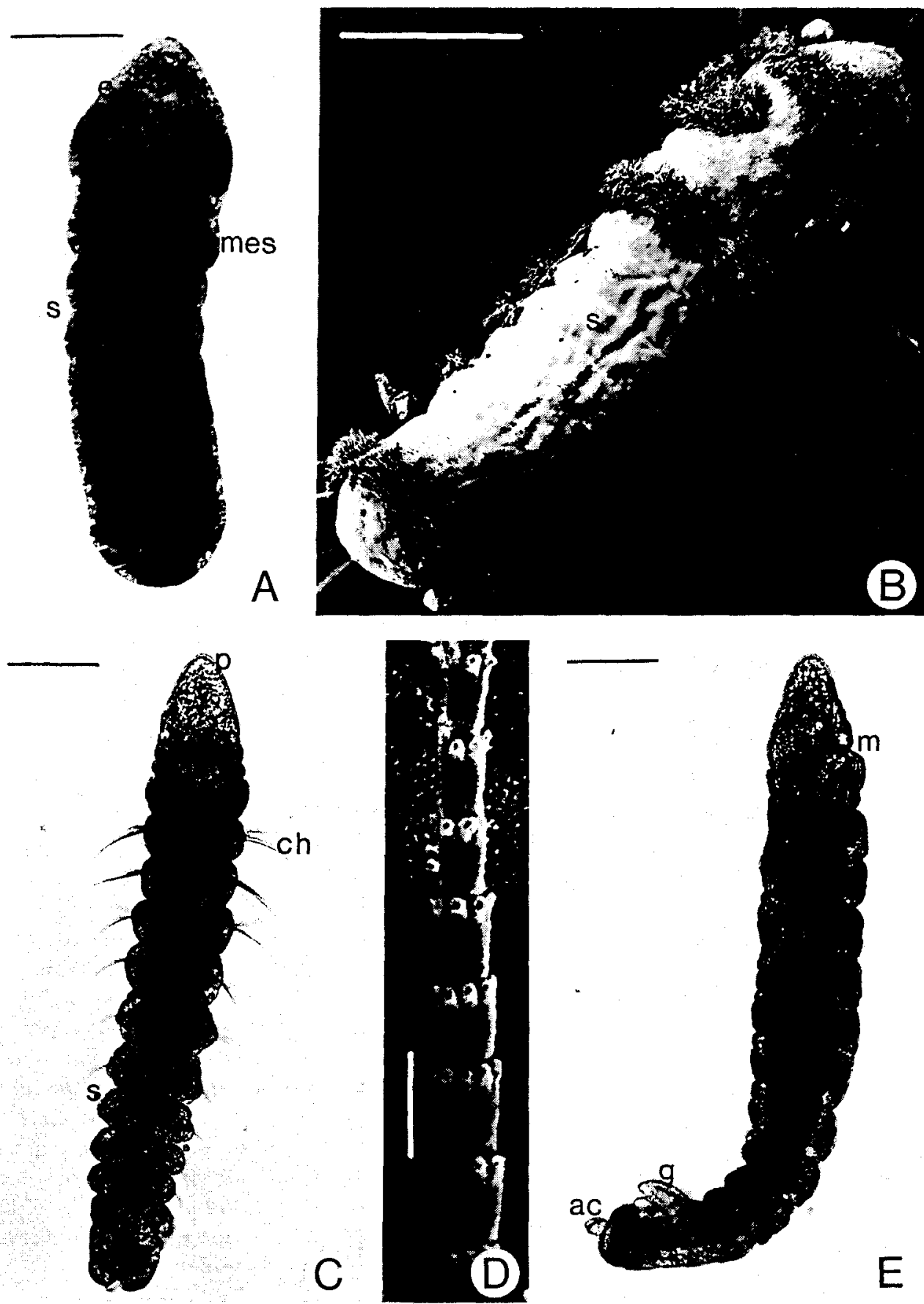

$E$ 

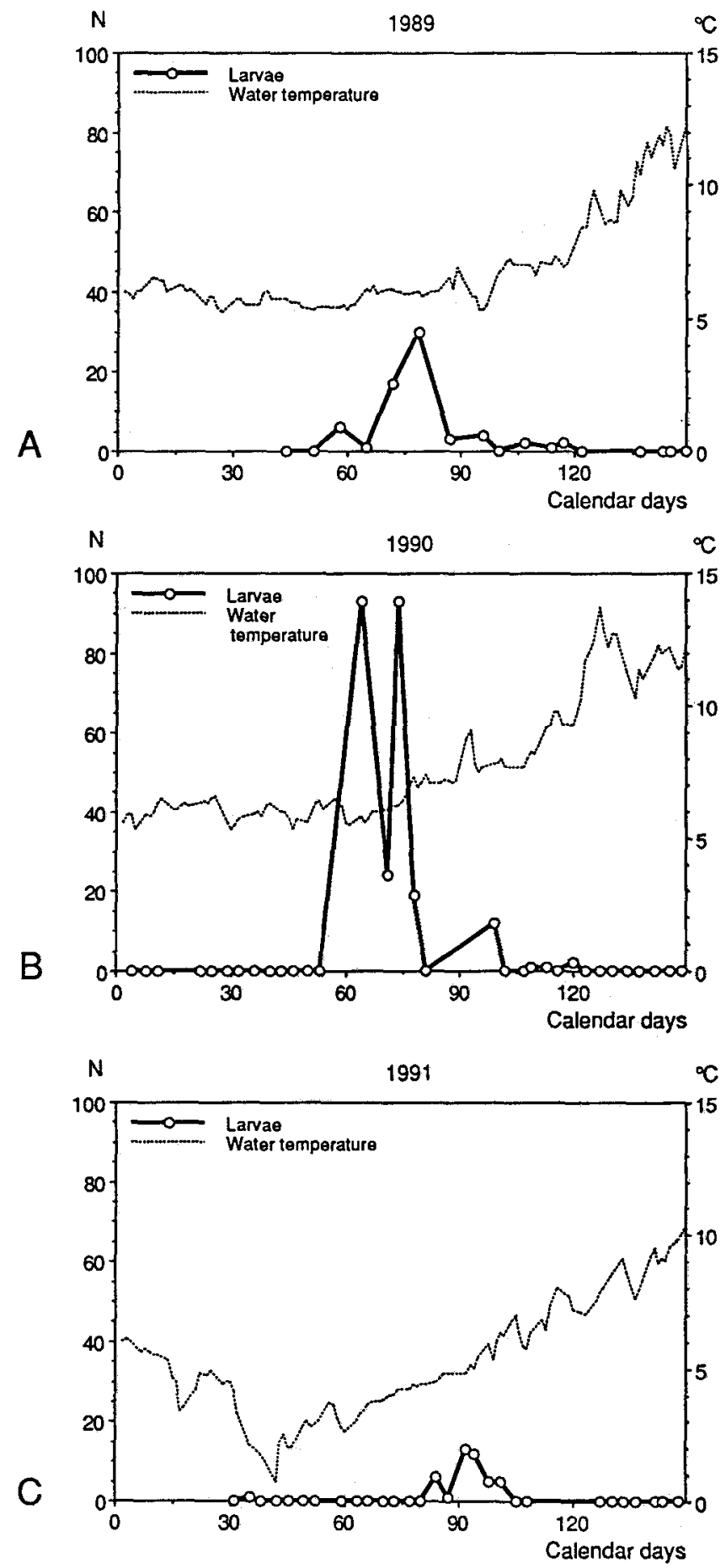

Fig. 2 A-C. Seasonal distribution and abundance of the planktonic larvae of Scoloplos armiger, and water temperature, in 1989-1991. N: Individuals per $\mathrm{m}^{3}$ 
following specimens were young stages with two to four setiger anlagen, and the last, found in mid-April, were larvae with four to nine setiger anlagen. Compared to the preceding years, the pattern of age structure was more uniform and followed the chronological developmental path. In 1991, spring water temperature was markedly lower than in 1989 and 1990, and the appearance of larvae was delayed by about 20 days (Fig. 2 C).

Our data do not indicate that reproduction via planktonic larvae is synchronized with tidal rhythms as described by Anderson (1959) and Chapman (1965) for reproduction via benthic egg cocoons.

\section{DISCUSSION}

Many investigators described the development of Scoloplos armiger as non pelagic (Delsman, 1916; Anderson, 1959; Chapman, 1965; Gibbs, 1968). Smidt (1951) reports the entire benthic development within egg cocoons from the Danish Waddensea, but his drawings of "Heteromastus filicornis" (page 66, Fig. 27) show pelagic larvae of S. armiger at different developmental stages. These larvae occurred in the autumn plankton while, in agreement with Anderson (1959) and Chapman (1965), egg cocoons were found from February to May. Giere (1968) also recorded single planktonic larvae in the Elbe estuary during autumn. He assumed that these larvae originated from a second spawning of the adults. Winter spawning was also described by Gibbs (1968). These observations pointed to two distinct reproductive phases: production of benthic egg cocoons in spring and pelagic larvae in autumn. The results of the present study give no indication of the occurrence of more than one spawning season. However, the additional possibility of a benthic development in egg cocoons cannot be excluded.

Both larval types differ only slightly in morphology, Pelagic larvae possess more numerous lateral ciliary bands. This may represent an adaptation to the pelagic mode of development.

The seasonally restricted presence of larvae indicates a strong reproductive synchrony. Anderson (1959), Chapman (1965) and Gibbs (1968) proposed that a distinct rise in water temperature in combination with spring tides effectively triggers off the spawning process. The present study gives no indication of a tidal periodicity. Wind and tide driven currents prevent an exact determination of the origin of the larvae, and may superimpose a potential lunar rhythm.

The delayed appearance of larvae in 1991 supports the hypothesis that reproduction is correlated with water temperature. Gibbs (1968) suggested that a rise in water temperature beyond $5{ }^{\circ} \mathrm{C}$ is essential for reproduction. According to our data, reproduction in 1991 must have started while water temperature was still lower than $5^{\circ} \mathrm{C}$. We presume that daylength is the zeitgeber for the onset of gametogenesis, and that a distinct rise in temperature promotes gametogenesis, and produces the ability to spawn. When temperature remains above the threshold for reproduction, daylength is the only factor responsible for synchronous gametogenetic maturation. Spawning as the final reproductive event may be triggered by additional factors such as spring tides.

Acknowledgements. Our thanks are due to the crew of the R. V. Aade for their assistance and also to P. Mangelsdorf for placing unpublished water temperature data at our disposal. We are grateful to Prof. Dr. D. K. Hofmann and Dr. H.-D. Franke for their constructive criticism on the manuscript. Parts of this work were supported by grants of the Biologische Anstalt Helgoland. 


\section{LITERATURE CITED}

Anderson, D. T., 1959. The embryology of the polychaete Scoloplos armiger, - Q. Jl microsc. Sci. 100, 89-166.

Chapman, G., 1965. The egg cocoons of Scoloplos armiger O. F. Müller. - Biol. Bull. mar. biol. Lab., Woods Hole $128,189-197$.

Delsman, H. C., 1916. Eifurchung und Keimblätterbildung bei Scoloplos armiger O. F. Müller. Tijdschr. ned. dierk. Vereen. 14, 383-498.

Gibbs, P. E., 1968. Observations on the population of Scoloplos armiger at Whitstable. - J. mar. biol. Ass. U.K. $48,225-254$.

Giere, O., 1968. Die Fluktuationen des marinen Zooplanktons im Elbe-Aestuar. - Arch. Hydrobiol. (Suppl.) 31, 379-546.

Jägersten, G., 1972. Evolution of the Metazoan life cycle. Acad. Press, London, 282 pp.

Muus, B. J., 1967. The fauna of Danish estuaries and lagoons; distribution and ecology of dominating species in the shallow water reaches of the mesohaline zone. - Meddr Danm. Fisk.-og Havunders. 5, 3-316.

Rachor, E., 1990. Changes in sublittoral zoobenthos in the German Bight with regard to eutrophication. - Neth. J. Sea Res. 25, 209-214.

Smidt, E. L. B., 1951. Animal reproduction in Danish Waddensea. - Meddr Kommn Danm. Fisk.-og Havunders. (Ser. Fiskeri) 11, 1-151.

Wolff, W. J., 1973. The estuary as a habitat-analysis of data on the soft-bottom macrofauna of the estuarine area of the rivers Rhine, Meuse and Scheldt. - Zool. Verh., Leiden 126, 1-242. 